\title{
Analysis of Different Views and Conceptualizations of the Literacy Practices of Pupils, Families, and Teachers in Costa Rican Primary Education
}

Fernando Guzmán-Simón, Celia Moreno-Morilla, and Eduardo García-Jiménez

\section{QUERY SHEET}

This page lists questions we have about your paper. The numbers displayed at left can be found in the text of the paper for reference. In addition, please review your paper as a whole for correctness.

Q1: Au: Please note that the ORCID for Guzmán-Simón Fernando has been created from information provided through CATS. Please correct if this is inaccurate.

Q2: $\quad$ Au: Please provide reference for citation [New London Group, 1996].

Q3: Au: Multiple reference elements are missing from [Authors, 2014]. Please supply information to complete it.

Q4: Au: Please provide missing [editor name or institutional editor name/publisher location] for [Molina Fallas \&Cruz Romero, 2013].

Q5: $\quad$ Au: Please cite [Palys \& Given, 2008] in text or delete reference.

Q6: $\quad$ Au: PISA - please spell out

Q7: $\quad$ Au: Authors 2014 - please show the author names

Q8: $\quad \mathrm{Au}$ : Authors 2014 - please show the author names

Q9: $\quad \mathrm{Au}$ : $\mathrm{T} 2$ - please confirm if this is a t squared test $\mathrm{OR}$ a $\mathrm{t}$ test?

Q10: $\quad$ Au: The objective is the aim - please confirm this sentence reflects your intent

Q11: Au: Figure 2 note - please provide an explanation for all "code words" shown in the figure.

\section{TABLE OF CONTENTS LISTING}

The table of contents for the journal will list your paper exactly as it appears below:

Analysis of Different Views and Conceptualizations of the Literacy Practices of Pupils, Families, and Teachers in Costa Rican Primary Education

Fernando Guzmán-Simón, Celia Moreno-Morilla, and Eduardo García-Jiménez 


\title{
Analysis of Different Views and Conceptualizations of the Literacy Practices of Pupils, Families, and Teachers in Costa Rican Primary Education
}

\author{
Fernando Guzmán-Simón (D), Celia Moreno-Morilla (1), and Eduardo García-Jiménez (1) \\ University of Seville, Seville, Spain
}

\begin{abstract}
This article is based on a socio-cultural discourse model of literacy, whereby literacy events are regarded as being situated within social practices, creating various formal, informal, and non-formal literacy events that are part of multiliteracies. The aim of the research was to analyze primary pupils' literacy practices (8-12 years) from the perspectives of 1,354 primary pupils, 1,020 family members, and 96 teachers in Costa Rica, using an ex-post facto design and a survey method. The findings indicate that the three groups of participants (pupils, family members, and teachers) have different views on and conceptualizations of literacy practices in school and in the community. The results show that young learners develop their literacy practices according to their different communicative needs inside and outside school. A multimodal literacy is promoted outside school to meet students' daily communicative needs. However, the school promotes a monomodal literacy, which allows pupils to respond essentially to school needs.
\end{abstract}

\section{ARTICLE HISTORY}

Received 25 May 2017

Accepted 14 January 2018

\section{KEYWORDS}

Formal and informal learning; literacy practices; multiliteracies; primary school education; reading and writing habits

Young learners' literacy in primary education (from age 8 - 12 years) serves a useful purpose. Children use reading and writing for a variety of reasons in everyday life, such as to find out the screening times at cinemas, to share a personal experience with friends using an app, or to find out the best procedure for returning a bought item. The ways in which literacy is used can vary according to context as pupils, their families, and teachers develop their writing and reading skills in different domains and situations of everyday life (Barton, 1991). This perspective with respect to literacy is based on the theoretical assumptions of social semiotics and the ethnography of communication (Gee, 1999; Halliday, 1978; Hymes, 1996; Maybin, 1994) as well as studies of literacy conducted by Barton (1994), Barton and Hamilton (1998), Baynham (1995), Gee (1990), and Street (1995).

Various reports on primary education (from 8 - 12 years) in Costa Rica (CONARE, 2013; Ministerio de Educación Pública [MEP], 2012) have shown limited improvement in literacy education over the last decade. When data are compared with European and Asian countries in international assessments (OECD, 2014, 2016), gaps in the field of literacy, in general, and reading comprehension, in particular, have been identified (Montero, Rojas, \& Zamora, 2014).

As a result of social changes introduced in Costa Rica in the last decade, it is necessary to incorporate information and communications technology (ICT) in schools as part of curriculum development and the transformation of teaching methodology (Molina \& Cruz, 2013). However, ICT use by teachers in the classroom is usually very limited, owing to the poor quality of technological resources and Internet connectivity. These same reports highlight the lack of teachers' methodological knowledge for incorporating ICT in the curriculum of the primary school classroom.

CONTACT Fernando Guzmán-Simón fernandoguzman@us.es Eacultad de Ciencias de la Educación, Universidad de Sevilla, C/ Pirotecnia, s/n, Sevilla 41013, Spain.

Color versions of one or more of the figures in the article can be found online at www.tandfonline.com/ujrc. 
All these elements highlight the need to better understand the various literacy events in which pupils of primary education engage and the domains in which they take place. The PISA tests (OECD triennial study of 15 -year students on reading, mathematics and scientific knowledge) (OECD, 2016) and the diagnostic tests administered in the second cycle in Costa Rica from age 9 to 12 years (MEP, 2013) reiterate the need to enhance understanding of literacy processes in the current context.

\section{Theoretical framework}

Barton (1994) has described literacy as situated social practices. More recently, Hamilton (2010) has highlighted how the view of literacy has changed from a "discrete set of skills" to a "situated social practice" (p. 9). The concept literacy practice was defined by Barton and Hamilton (2000) as a "way of conceptualising the link between the activities of reading and writing and the social structures in which they are embedded and which they help shape" (p. 6). The concept of literacy practice describes the literacy awareness of a specific population, as well as the contexts or situations in which people make use of literacy. However, these practices cannot be observed directly, so we must first analyze the literacy events of daily life (Street, 2000). The concept of literacy events was developed first by Heath (1983) and Street $(1984,1988)$, and reworked by Street (2000). Literacy events are defined by Barton and Hamilton (2000) as "activities where literacy has a role. Usually, there is a written text, or texts, central to the activity and there may be talk around the text. Events are observable episodes that arise from practices and are shaped by them" (p. 8). These literacy events are present in several daily and routine activities carried out by young learners in primary education, where different styles of formal, informal, and nonformal learning, oral and written, take place. Within the literacy events, literacy practices are established that relate to certain contexts, cultural frameworks, or communities (Street, 1997). Street (1994) highlights "the social uses and meanings of reading and writing" (p. 116) in literacy practices. Therefore, the analysis of literacy practices needs to takes into account the literacy events and the social meaning of those events.

The approach chosen for our research is based on the ideological rather than the autonomous model of literacy (Street, 1994). The autonomous model is based on a set of "technical and neutral skills" that do not differ depending on the context and culture in which they occur and "has dominated curriculum and pedagogy" (Street, 1994, p. 120). In contrast, the ideological model refutes the neutrality of the autonomous model and emphasizes the sociocultural context of literacy. A systematic investigation of such writing and reading practices could help us identify those literacy practices in which the pupils of primary education, their families, and teachers engage, as well as the relationships established among the various domains such as home, school, and community, among others. In the various social contexts in which the young learners, families, and teachers participate, members share a number of conventions in terms of the objects of communication, discourse structure, writing style, and so on (Harris, 1989). Currently, the writing and reading practices of pupils, within and out of school, are not known, nor how these relate to the language and literacy activities in Costa Rican primary schools.

Our analysis of literacy practices takes into account the particular context in Costa Rica, the use of technology, and the ways in which literacy activities were conducted (for a wider discussion, see Maybin, 2006) by primary school pupils in different communities and social domains. These elements constitute an ecological approach, as defined by Barton's literacy concept (1994). Martos García (2010) described four social ecosystems where literacy events are grouped. These events (situated and social activities) interact with several literacy practices and the environment according to the following classification: 
(1) Personal literacy: individual activities that involve reading and/or writing in different places and domains of non-formal and informal learning (e.g., individual literacy events or groups outside the scope of school).

(2) Culture of instruction: social activities in which reading and/or writing are present in different places and domains of formal learning (e.g., reading and writing tasks and activities required at school).

(3) Library culture: activities in which reading and/or writing are present in different locations, such as the use of public or private libraries.

(4) Cultural consumption: Activities in which reading and/or writing are present in different places and domains related to the purchase/sale of literate products (e.g., literacy events related to the publishing market).

Due to literacy practices in our society, children's literacy occurs not only within school, but also in other places such as in their community and at home (Neuman \& Celano, 2001). The various domains present relationships of codependency with each other, where the ecological character of literacy focuses on how young learners, families, and teachers interact with the literacy sources of a community with which they identify.

Thus, the ecological approach allows us to observe how the literacy practices of pupils are built on the interaction of different domains and spaces, which means taking a holistic approach to oral and literate communication by focusing on the context (Pahl \& Rowsell, 2012). The social events frame the local and global literacy practices, where physical locations (such as bookstores or libraries) and virtual ones (such as Twitter, Facebook, or WhatsApp) determine the type of literacy practice in which young learners need to be competent. Thus, Brandt and Clinton (2002) preferred to determine the literacy events as "localizing moves" and "globalizing connects," where "local human agents can be involved in globalizing work, whether in such overt acts as, say, data processing or in the more subtle representation of global interests in local literacy actions" (p. 351).

Digital technology has transformed the nature of local interactions (Lillis, 2013). This transformation is observable in schools (Maybin, 2006) where formal literacy (developed in an academic environment, directed by a leader/teacher and assumed as a model) is mixed with everyday experiences of informal (as the self-acquired literacy, defined by its holistic and self-directed approach) and nonformal literacy (acquired from a leader/teacher serving as a model, in nonacademic or conventional environments) (Folkestad, 2006). Indeed, the ecological approach to literacy has incorporated the concept of multiliteracies (Cope \& Kalantzis, 2009) in multimodal contexts (Kress, 2010), which emphasizes a system of hybrid literacy that combines print and digital elements (Kalantzis \& Cope, 2000). The focus of research into multiliteracies has been on the changes in literacy practices experienced by participants, in the context of communicative practices (New London Group, 1996). In it, multimodal and nonlinguistic forms of communication interact with other linguistic forms (Jewitt, 2008). The latest developments have been several literate practices in multimodal or monomodal, according to the media used for communication (Flewitt, 2006; Walsh, 2010).

The adoption of hybrid literacy by the various actors to engage in multimodal discourse enhances metadiscoursal knowledge of the various modes of a communication system and various sociocultural contexts (Kress, 2003). This situation takes place, for instance, when buying items at a website on the Internet or sending WhatsApp messages. The widespread access to digital technology from an early age has greatly changed the social practices of reading and writing in primary education (Barton \& Lee, 2012).

To investigate the literacy practices of primary pupils, we have focussed on the following objectives: 
(1) Describe the literacy events and practices of primary school pupils in Costa Rica using the different dimensions (personal literacy, culture of instruction, library culture, and cultural consumption).

(2) Identify differences in young learners' literacy practices from the perspectives of family members, teachers, and the pupils themselves.

(3) Compare the literacy practices of pupils in different domains (home, school, and community) of Costa Rica with the data provided by young learners, families, and teachers.

\section{Methodological framework}

To describe pupils' literacy events, we asked pupils, students, and teachers to complete a survey. This description has relied on self-administered questionnaires (Clerehan, Guillermin, Epstein, \& Buchbinder, 2016; Lavrakas, 2008) completed by the participating young learners, some of their family members, and their teachers. We have also studied the relation between the opinions of these three groups regarding the literacy events. An ex-post-facto analysis completed this quantitative research approach to verify the existence of differences in these events in terms of the different actors (Creswell, 2009; Gil-Flores, Torres-Gordillo, \& Perera Rodríguez, 2012).

All the participants (teachers, pupils, and families) in the current research were informed about the nature of the study and the conditions of their participation. This participation was voluntary and followed the informed-consent rules, which restrict the use of information for research purposes only, and its confidentiality. This article has followed the internal regulation in Social Sciences by the Ethical Committee of Experimentation of the University of Seville.

\section{Sample}

We studied the reading and writing practices of primary education pupils (age $8-12$ years). Specifically, young learners participated from seven schools in different provinces of Costa Rica (Alajuela, Heredia, San José, and Cartago). To ensure the diversity of the sample, these centers were chosen based on the following criteria: representation of public and private schools, proportionality of boys and girls at each school (50\% each), representation of different ages ( $8-12$ years), proportionality in the number of children in each educational level, and proportionality of location (urban, semi-rural, and rural).

In the sample of schools, all the pupils participated, completing 1,354 self-report questionnaires in total. Similarly, a family member of these pupils filled in 1,020 self-reports. Finally, 96 teachers of the pupils filled in self-reports of their own literacy events and those they taught.

\section{Research instruments}

The information was collected through completion of questionnaires in three versions, each of which was completed in printed or online form, depending on the availability of the Internet. ${ }^{1}$ The questions on the three versions of the questionnaire were the same, except the items referring to the instructional literacy for parents and the items about personal literacy for teachers.

The self-report method of data collection was based on an ecological approach to literacy (Douglas, 1970) and the approach of literacy studies (Barton, 1994; Barton \& Hamilton, 1998; Baynham, 1995; Gee, 1990; Maybin, 1994; Street, 1995). Based on this approach, questionnaires were constructed using four different classifications of literacy events: personal literacy (e.g., Where do you usually read? Which means/format do you usually use for writing? When you type on a digital media, where do you usually do it?), cultural consumption (e.g., Where do you usually buy books? Which events/activities related to reading or writing have you attended?), library culture (e.g., What do you usually use libraries for?), and culture of instruction (e.g., 
What kind of text do you read more frequently at school? How are the readings recommended by the teacher used in class? After reading the texts recommended, what kind of written activities do you do?) (Martos García, 2010).

There was a standard procedure for administering the questionnaires. The printed version of the questionnaire was completed in an ordinary classroom and the online version in a computer room. For both versions, a researcher introduced the questionnaire, giving examples of how they might respond as well as giving the children and teachers the opportunity to ask questions. The families' questionnaire was sent in printed version to their homes with instructions.

The self-report questionnaire in its various versions was prepared by Authors (2014) for a Spanish sample. The validity and reliability of this instrument were derived from a Non-Metric Multidimensional Scaling (PROXSCAL) (see Figure 1) (Authors, 2014). However, the items on the questionnaire were expressed in the local vernacular, incorporating terms and expressions characteristic of the Spanish language spoken in Costa Rica. In this article, we have analyzed only the 29 items common to all three versions. Each of the items was assessed using a Likert-type scale from 0 (never) to 5 (always).

\section{Data analysis}

The analysis of the responses to all the items obtained from the self-report questionnaires took into account the dimensions of the literacy events. Thus, a descriptive analysis was conducted based on the calculation of the arithmetic averages and Standard Deviations of the responses. Similarly, comparisons were made to determine the differences in the self-report questionnaires of pupils, families, and teachers for which an analysis of variance was used. After applying the Levene test, it was determined that there was homogeneity of variances. Tamhane's $\mathrm{T}^{2}$ test is suitable for a post-hoc analysis and was used to compare the means between groups (Upton \& Cook, 2014).

To study the relationships between the different dimensions of the self-report questionnaires, factor analyses were conducted for each of the three versions of self-report questionnaires. The extraction method used was principal components and the rotated factor solution was obtained using the varimax method (Jolliffe, 2013). A second-order factor analysis was performed based on the rotated factors obtained in the first analysis.

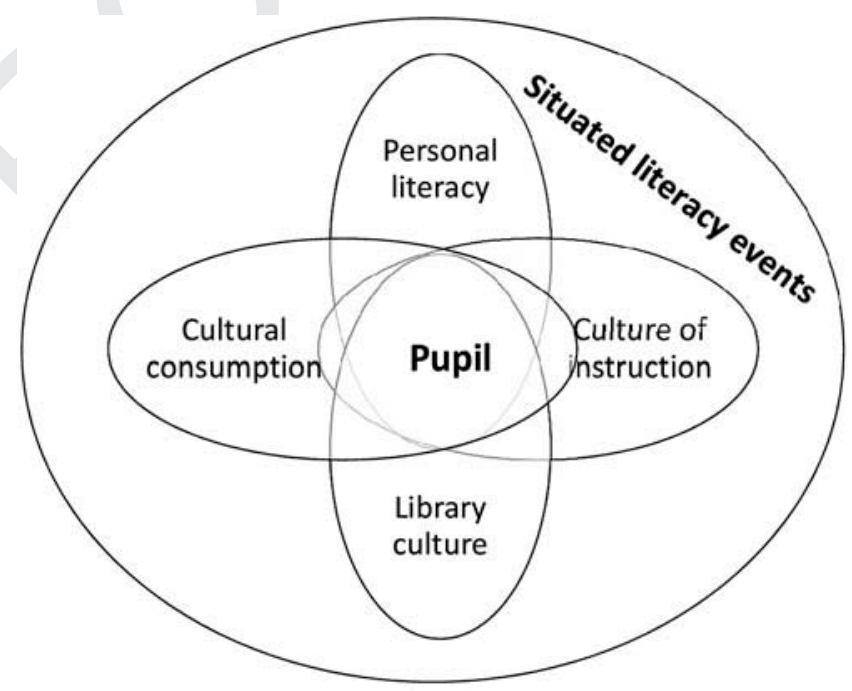

Figure 1. Situated literacy events dimensions. Adapted from Martos García (2010). 
Findings

The results of this research first address the description of literacy events and practices in their various dimensions (personal literacy, culture of instruction, library culture, and cultural consumption), according to the first objective of our inquiry. Table 1 shows the averages corresponding to the items of each of the dimensions of the self-report questionnaires in the versions for young learners, families, and teachers. In these, we see that teachers are the ones who get the highest scores in the dimensions of cultural consumption and culture of instruction. Pupils, in turn, are the ones who get the highest scores in the dimensions of cultural literacy and library culture; we note that there are no items related to teachers in the latter.

The results are salient to the extent that they show the different perspectives of pupils, families, and teachers regarding the same literacy events and practices (Table 1). According to pupils, their personal literacy is developed especially at home, making use of printed reading and writing, such as reading and writing on the screen (mobile phones, computers, and tablets). On the other hand, literacy in school is mainly developed through the reading of fiction, textbooks, and photocopied extracts or handouts. The activity that teachers most frequently perform with their students is the analysis of readings, and the most demanded school tasks are abstracts and conceptual maps, to the detriment of the debates, reflections of the students, and personal comments on reading and writing. Pupils highly value reading and writing in social networks among their school tasks. Conversely, events related to cultural consumption (attendance at book fairs, storytelling, etc.) and use of a library have a low score.

Table 1. The mean value of items shared among pupils, families, and teachers from all centers.

\begin{tabular}{|c|c|c|c|c|c|}
\hline Dimension/Items & & Pupils & Families & Teachers & Sig. in favor of \\
\hline \multirow[t]{9}{*}{ Personal literacy } & At home & 3.46 & 2.42 & 4.34 & Teachers \\
\hline & At school & 2.79 & 3.15 & 3.06 & Families \\
\hline & At the library & 1.16 & 2.33 & 1.65 & Teachers \\
\hline & On paper & 4.26 & 2.50 & 4.38 & Teachers \\
\hline & On the computer & 3.69 & 2.75 & 4.43 & Teachers \\
\hline & On the mobile phone & 3.93 & 2.49 & 3.09 & Students \\
\hline & On a tablet & 3.05 & 2.52 & 1.05 & Students \\
\hline & Social networks & 3.20 & 2.16 & 2.92 & Families \\
\hline & Blogs & 1.74 & 2.32 & 1.19 & \\
\hline Total & & 3.03 & 2.51 & 2.90 & \\
\hline \multirow[t]{5}{*}{ Cultural consumption } & In a bookshop & 1.77 & 3.59 & 4.48 & Teachers \\
\hline & On internet & 1.60 & 0.38 & 1.23 & Students \\
\hline & Book fair & 2.02 & 1.37 & 1.70 & Students \\
\hline & Storytelling & 1.86 & 0.88 & 1.48 & Students \\
\hline & Writing workshop & 1.89 & 0.34 & 1.11 & \\
\hline Total & & 1.83 & 1.31 & 2.00 & \\
\hline \multirow[t]{4}{*}{ Library culture } & As a reading room & 2.52 & 1.22 & - & Students \\
\hline & Doing group projects & 2.38 & 1.53 & & Students \\
\hline & For book borrowing & 1.88 & 1.65 & & Students \\
\hline & For Internet access & 1.81 & 0.72 & & \\
\hline Total & & 2.15 & 1.28 & - & \\
\hline \multirow[t]{11}{*}{ Culture of instruction } & Textbooks & 3.18 & - & 4.47 & Teachers \\
\hline & Magazine articles & 1.51 & & 2.99 & Teachers \\
\hline & Reading books & 3.30 & & 3.92 & Teachers \\
\hline & Class notes & 3.07 & & 4.30 & Teachers \\
\hline & Photocopies & 3.23 & & 4.28 & Teachers \\
\hline & Hold a debate & 0.98 & & 2.66 & Teachers \\
\hline & The students reflect & 2.68 & & 3.82 & Teachers \\
\hline & The teacher analyzes readings & 3.35 & & 4.16 & Teachers \\
\hline & Summaries & 3.48 & & 4.08 & Teachers \\
\hline & Outlines or concept maps & 3.35 & & 4.00 & Teachers \\
\hline & Personal comments & 2.70 & & 3.51 & Teachers \\
\hline TOTAL & & 2.80 & - & 3.83 & \\
\hline
\end{tabular}


The opinion that families have about the personal literacy of their children points to the school as the main place where literacy develops. Reading and writing on the computer (followed by the tablet and handwriting) are the means most often mentioned by families, to the above reading and writing on social networks or mobile phones. The overall cultural consumption is focused on bookstores, while the rest of the items yield very low scores.

Teachers' perspectives on their personal literacy shows that their literacy is developed at home and is based on the use of computers and handwriting (surpassing the use of the tablet or mobile phone). Teachers focus on a culture of instruction through textbooks, photocopies, and class notes. The tasks they demand of their students are summaries and conceptual maps. Teachers' cultural consumption is focused on bookstores and contrasts with the low score of other modes of cultural consumption (internet, book fairs, etc.).

The comparative analysis of the dimension personal literacy allows us to infer that families perceive that their children read mainly at school, whereas pupils and their teachers think they do so more often at home. Also, families differ from teachers and young learners in their assessment of the use of digital media in general and writing on the computer in particular. Similarly, the consideration of reading and writing in social networks differs when the perception of the pupils and teachers is compared with that of the families. In the opinion of the latter, the literacy process of their children occurs mainly at school, which becomes the dominant literacy agent.

The use of an analytic procedure such as factor analysis helped us reduce the complexity observed in the responses of the three participant groups to the 29 items. Thus, we have identified differences in young learners' literacy practices from the perspectives of family members, teachers, and the pupils themselves, according to the second aim of our research. Because there are significant differences between the three groups in almost all of the items, we have carried out a reduction from three factor analysis, one for each of the three groups of participants involved. The solutions obtained have identified principal components associated with each of the three groups involved in the investigation. These components are only related to the dimensions of personal literacy and culture of instruction; for the remaining dimensions, main components were not found that explained the variability observed in the self-report questionnaires of pupils, families, and teachers. As a consequence, the dimensions of cultural consumption and library culture were not considered in subsequent analysis (see Table 2).

The first dimension shown in Table 2, personal literacy, helps explain the responses of pupils and families from the manner of literacy (monomodal and multimodal) and the responses of teachers from the ways of learning literacy (formal vs, nonformal and informal). The main component, monomodal literacy practices, explains the items that are related to reading in print that are performed in different domains (family, neighborhood, school, community of friends, etc.). However, the second major component, multimodal literacy practices, explains the items of multimodal writing that took place in global domains (writing on the computer, mobile phone, social networks, blogs, etc.).

The analysis of the principal components performed from the responses of teachers reduces the variability of the items into two components (see Table 2), which refer to the ways of learning

Table 2. Main components associated with each of the writing and reading participants and dimensions, with the percentage (in parentheses) of variance explained after rotation.

\begin{tabular}{llll}
\hline $\begin{array}{l}\text { Actors } \\
\text { Dimensions }\end{array}$ & \multicolumn{1}{c}{ Pupils } & \multicolumn{1}{c}{ Families } \\
\hline Personal literacy & $\begin{array}{l}\text { Monomodal literacy practices } \\
(27.47)\end{array}$ & $\begin{array}{l}\text { Monomodal literacy practices } \\
(27.54)\end{array}$ & Formal literacy practices (29.80) \\
& $\begin{array}{l}\text { Multimodal literacy practices } \\
\text { Multimodal literacy practices } \\
(26.13)\end{array}$ & $\begin{array}{l}\text { Informal and Non-formal literacy } \\
\text { practices (22.09) } \\
\text { Unidirectional literacy practices (28.13) }\end{array}$ \\
$\begin{array}{ll}\text { Culture of } \\
\text { instruction }\end{array}$ & $\begin{array}{l}\text { Unidirectional literacy practices } \\
(22.68)\end{array}$ & & \\
& Multidirectional & & Multidirectional literacy practices (30.31) \\
\hline
\end{tabular}


(formal/informal and nonformal literacy). Thus, though teachers know that there are literacy practices in different media (print, tablet, blogs, etc.), these practices serve different purposes: in the first component, formal literacy practices, the student literacy events are related to professional work of teachers in the school domain; the second component, nonformal/informal literacy practices, is linked to the activity of teachers outside the school domain (personal, social, etc.). In both components, literacy practices incorporate multimodal codes.

The second dimension contained in Table 2, culture of instruction, refers only to pupils and teachers. Here, too, two main components were obtained. In the first component, called "unidirectional literacy practices," tasks assigned by teachers are based on the use of reading books, textbooks, or photocopies and the creation of summaries. The second component, called "multidirectional literacy practices," refers to the tasks assigned by teachers and involve literacy practices in which young learners learn through discussion, reflection, analysis of readings, and the development of outlines or conceptual maps.

In this same dimension, the analysis of the principal components drawn from the responses of teachers also identifies two components that explain in an analogous way the variability observed in the items. However, multidirectional literacy practices refer to tasks involving debate, reflection on and analysis of texts, as well as the use of textbooks and photocopies, which, in the case of pupils, were among the unidirectional practices. Consequently, while loading on to the unidirectional/multidirectional axis, teachers and pupils introduce differentiating nuances in describing the culture of instruction.

The third objective of our analysis was the comparison of the literacy practices of pupils in Costa Rica in different domains, such as home and school, from the point of view of young learners, families, and teachers. A joint analysis of the self-report questionnaires completed by the three groups, made through a factor analysis of second-order analysis, draws out connections among the components described above (see Table 3). In this analysis, we see how, in the first principal component, responses to items related to the multimodal literacy practices of pupils and families are explained. Families gave a high score for their children's use of computers for reading and writing (0.703) in terms of personal literacy outside school. This viewpoint is analogous to that of the children, whereas the perspective of teachers differed. According to the teachers, children read (at home, at the school, and in libraries) and perform handwriting as part of their monomodal literacy practices linked to the school (0.688). These practices are also unidirectional, given that the children read textbooks or take notes during the classes even when this reading and writing serves neither a situated nor social function (0.797).

On the contrary, in the second principal component, the items related to pupils' unidirectional literacy practices, the monomodal practices of pupils, families, and teachers' multidirectional practices are all explained. On the one hand, children and their families link monomodal literacy practices to school reading and handwriting ( 0.843 and 0.773 , respectively). Children consider their reading and writing tasks as unidirectional literacy practices $(0.752)$, where literacy as a social and situated function is not promoted. On the other hand, teachers' opinions about the literacy activities performed in the classroom are completely different. They believe that multidirectional literacy practices in the classroom are frequent (0.297).

A graphic representation of these rotated components may show a clearer perspective of the relationship among the dimensions of literacy practices and agents (see Figure 2).

As shown in Figure 2, the elements that best discriminate on the vertical axis correspond to the scores of pupils and their families in the monomodal literacy practices (V_monomodal_literacy_S, V_monomodal_literacy_F) component, and pupils in the component unidirectional literacy practices (IC_unidireccional_literacy_S). In the horizontal axis, the most discriminative elements lie in scores associated with the formal literacy practices (V_formal_literacy_T) component referred to teachers and multimodal literacy practices (V_multimodal_literacy_F) for the families component. Similarly, it is observed that, though the vertical axis consists mainly of literacy practices of pupils, the horizontal axis represents the best literacy practices of teachers. In the case of families, the presence of the dimension personal literacy (V_multiliteracy_F) would indicate that they consider that the use of digital media for writing in the "home" domain to be an eminently social event. 
Table 3. Dimensions of literacy practices according to the three agents.

\begin{tabular}{|c|c|c|c|c|}
\hline \multirow{2}{*}{ 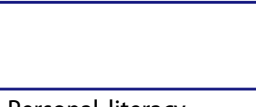 } & \multirow[b]{2}{*}{ Pupils } & & \multicolumn{2}{|c|}{ Components } \\
\hline & & & 1 & 2 \\
\hline \multirow[t]{2}{*}{ Personal literacy } & Monomodal literacy practices & $\begin{array}{l}\text { Pupils read at home } \\
\ldots \text { read at school } \\
\ldots \text { read at the library } \\
\ldots \text { write on paper }\end{array}$ & 0.049 & 0.843 \\
\hline & Multimodal literacy practices & $\begin{array}{l}\text { Pupils type on the computer } \\
\ldots \text { type on the mobile phone } \\
\ldots \text { type on a tablet } \\
\ldots \text { post on social networks } \\
\ldots \text { type on Blogs }\end{array}$ & 0.456 & 0.037 \\
\hline \multirow[t]{3}{*}{ Culture of instruction } & Unidirectional literacy practices & $\begin{array}{l}\text { Pupils read textbooks } \\
\ldots \text { read books } \\
\ldots \text { read class notes } \\
\ldots \text { read photocopies } \\
\ldots \text { do summaries }\end{array}$ & 0.120 & 0.752 \\
\hline & Multidirectional literacy practices & $\begin{array}{l}\text { Pupils read magazine articles } \\
\ldots \text { do reflections } \\
\ldots \text { hold debates } \\
\ldots \text { do personal comments } \\
\text { Teachers analyze readings } \\
\ldots \text { offer outlines or conceptual maps }\end{array}$ & 0.171 & 0.074 \\
\hline & Familie & & 1 & 2 \\
\hline \multirow[t]{3}{*}{ Personal literacy } & Multimodal literacy practices & $\begin{array}{l}\text { My son/daughter types on the computer } \\
\ldots \text { types on the mobile phone } \\
\ldots \text { types on a tablet } \\
\ldots \text { posts on social networks } \\
\ldots \text { posts on Blogs }\end{array}$ & 0.703 & -.138 \\
\hline & Monomodal literacy practices & $\begin{array}{l}\text { My son/daughter reads at home } \\
\ldots \text { reads at school } \\
\ldots \text { reads at the library } \\
\ldots \text { writes on paper }\end{array}$ & -.096 & 0.773 \\
\hline & Teache & & 1 & 2 \\
\hline \multirow[t]{2}{*}{ Personal literacy } & Formal literacy practices & $\begin{array}{l}\text { Pupils read at home } \\
\ldots \text { read at school } \\
\ldots \text { read at the library } \\
\ldots \text { write on paper }\end{array}$ & 0.688 & -.001 \\
\hline & Non-formal/informal Literacy practices & $\begin{array}{l}\text { Pupils type on the computer } \\
\ldots \text { type on the mobile pone } \\
\ldots \text { type on a tablet } \\
\ldots \text { post on social networks } \\
\ldots \text { type on Blogs }\end{array}$ & -.148 & -0.222 \\
\hline \multirow[t]{2}{*}{ Culture of Instruction } & Multidirectional practices & $\begin{array}{l}\text { Pupils read photocopies } \\
\ldots \text { do reflections } \\
\ldots \text { hold debates } \\
\ldots \text { make personal comments } \\
\text { Teachers analyze readings }\end{array}$ & 0.148 & 0.297 \\
\hline & Unidirectional practices & $\begin{array}{l}\text { Pupils read textbooks } \\
\ldots \text { read magazine articles } \\
\ldots \text { read class notes } \\
\ldots \text { do summaries } \\
\ldots \text { make personal comments }\end{array}$ & 0.797 & 0.121 \\
\hline
\end{tabular}

\section{Discussion}

The results obtained lead us in our discussion to a series of principles characterizing literacy events in primary school pupils (from $8-12$ years), highlighting differences between the viewpoints of those young learners, their family members, and teachers. In this section, we will justify each principle in terms of the literacy practices that are performed in distinct domains. 


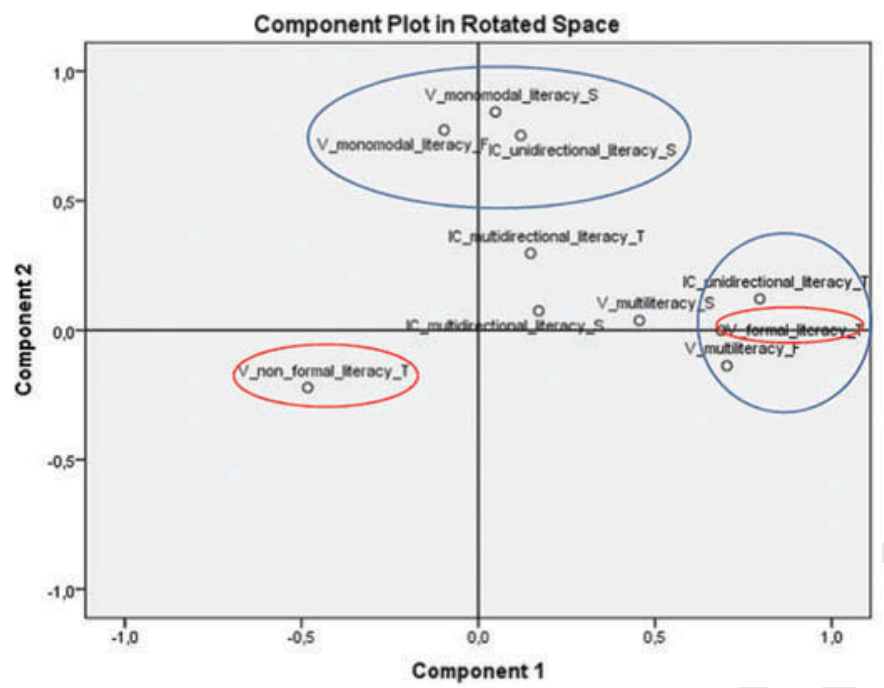

Figure 2. Coordinate axis graph obtained from the second order factor analysis.

The first objective of our research was to describe the literacy practices of young learners. We found that literacy practices were understood differently depending on who was describing them. Family members reported that, in the home domain, pupils develop literacy-related events related to monomodal codes when performing homework, as well as multimodal codes linked to the use of digital technology (computers, tablets, mobile phones, etc.) in response to nonschool demands (e.g., friends). On the other hand, teachers believe that individual reading and writing activities are explained to a greater extent by the formal literacy practices component. This means that, from the perspective of teachers, young learners develop their literacy practices related to school in the home domain.

In addition, pupils develop different literacy practices according to the domain in which they occur. At school age, the set of domains that best explains the literacy events of pupils are the dimensions of personal literacy and culture of instruction. For young learners, the literacy events are related to the demands that take place either in the domains of the home, friends, neighborhood, or in the school domain. According to such demands, the student develops nonformal and informal practices through the use of different digital media (computer, mobile phone, tablet, etc.), and through participating in social networks (e.g., Facebook, Twitter) as well as writing blogs. Such nonformal and informal practices tend to predominate in domains that are mainly located in individual reading and writing activities (Barton \& Hamilton, 2000; Ivanič et al., 2009). In the school domain, pupils receive demands to which they respond with formal practices (reading textbooks, conducting activities of literary creation, etc.) (Ames, 2005; Cox \& Robinson-Pant, 2005; Larson, 2005). These institutional practices are related to the social activities of reading and writing related to the formal learning. The use of the mobile phone in different domains is an excellent example of how young learners integrate nonformal and informal practices originating from individual reading and writing practices into the school domain. The dual perspectives of the pupils and families with regard to digital media is of interest; so, whereas families consider computer use as a literacy practice, they do not consider mobile phone use in the same way. In contrast, according to pupils, the mobile phone is a writing tool in addition to a computer (Tierney, Bond, \& Bresler, 2006).

The objective is the aim so it needs rephrasing. The second objective was to analyze the differences in young learners' literacy practices from the perspectives of family members, teachers, 
and the pupils themselves. We found that the home domain exerts a stronger influence in multiliteracies than does the school domain (Ivanič et al., 2009). On the one hand, the school domain has a monomodal literacy centered on school materials and carried out in print or written by hand. In the home domain, when pupils use a computer, they normally do so to complete a school assignment. On the other hand, multimodal literacy (Bezemer \& Kress, 2008; Lancaster, 2003; Pahl, 2003) is developed in individual reading and writing activities in the domains of the home, friends, neighborhoods, and the like, through the use of a mobile, tablets, and so on.

Family members show that it is in the home domain where multimodal literacy practices tend to take place, which results in frequent use of various digital technologies (computers, tablets, mobile phone, etc.). Consequently, multiliteracies are developed mainly in individual reading and writing activities, where the domains of home, communities of friends, and so on, promote multimodal literacy practices. At the opposite end are the monomodal literacy practices developed at the school domain under the social activities of reading and writing related to formal learning (Barton \& Lee, 2012; Gee, 2004; Knobel \& Lankshear, 2007; Maybin, 2006; Merchant, Gillen, Marsh, \& Davies, 2013; Street \& Street, 1991).

Consequently, there is little awareness of literacy events and practices in dimensions other than the social activities of reading and writing in school. There is little social awareness of literacy events located in nonschool domains (Bearne, 2003). For teachers, the various technologies (especially mobile phones and tablets) and social media (social networks, blogs, etc.) are not relevant in the classroom, making learning promoted at school unrelated to student multiliteracies (Carrington, 2005; Healy, 2008; Lankshear \& Knobel, 2003). This circumstance lessens the authenticity of the writing and reading practices offered by teachers, weakens student motivation toward the literacy tasks, and widens the gap between school and social practices (Pahl \& Rowsell, 2012).

The third objective was to compare the literacy practices of Costa Rican pupils in different domains. We found that the development of multiliteracies takes place in several domains and focuses on personal reading and writing activities. The computer meets the needs arising from homework and social networks. However, the computer competes with the mobile phone and tablet in social networks in several domains. Communication through social networks involves a more complex use of a multimodal environment, where pupils require multiliteracies (visual, audio visual, verbal, etc.) to be proficient in communication through the Internet.

Therefore, poor training at school regarding multiliteracies makes it impossible to attain an optimal development of digital, informational, and audio-visual skills in other domains. The development of multiliteracies in pupils is carried out in a global domain outside of school (home, friends, bookstore, library, etc.). This means that the multiliteracies required to understand and construct a multimodal text is limited to personal reading and writing activities, such as using social networks (Larson, 2006). The school does not sufficiently develop the strategic components (use of various digital media, digital and nondigital texts, multimodal composition of texts, etc.) of competence in linguistic communication (Walsh, 2010). However, such multiliteracies are not transferred from the domains of the home, friends, neighborhood, and so on, to the school domain. For these competencies to be part of learning, homework needs to incorporate multimodal literacy practices, using various modes in written communication (Davies, Halford, \& Gibbins, 2012; Warchauer, 2007). In this regard, a new literacy requires different or additional training for teachers (Cervetti, Damico, \& Pearson, 2006; Luke, 2000).

\section{Limitations and directions for future research}

The results obtained in this work have allowed us to obtain an overview of the literacy events and practices of pupils. However, there are some issues that future research should address. For instance, in our research, the main caregiver completed the questionnaire. In a few cases, this was a grandparent rather than a parent. In future research, it would be useful to record the number of responses 
per household as well as the proportion of parents or other relatives who complete the questionnaire. Indeed, future research into the influence of other family members, such as siblings, would contribute to a fuller understanding of the development of multiliteracies in different domains.

A further limitation is that we have not been able to study the literacy practices of participants in depth. For this reason, we would wish to complement our quantitative study with a qualitative one, which would allow us to gain greater insight into how literacy practices are influenced by school, home, and other contexts.

Future research should address the problem of literacy through a more qualitative approach. This type of methodology could help to overcome the limitations identified in this study and to complement the analysis performed here (Ivankova, Creswell, \& Stick, 2006). A qualitative approach, supported by the use of naturalistic observation and in-depth interviews, would provide an opportunity to focus on oral literacy practices and literacy events that have not been analyzed in the current study.

The research report here could be the first phase of a mixed methods design, with the second phase employing a more qualitative method. Such a qualitative approach should provide a deeper understanding of the practices and literacy events of young learners, family members, and teachers, and how these interact. The mixed method (Creswell \& Plano Clark, 2011; Tashakkori \& Teddlie, 1998) would obtain a double vision and a deeper perspective on the practices and literacy events of a purposive sample of pupils, parents, and teachers (Compton-Lilly \& Halverson, 2014; Hull \& Schultz, 2002; Lytra, 2007; Rogers \& Elias, 2012).

\section{Conclusion}

The research was founded on the perspective of literacy as a social practice (Barton, 1991; Barton \& Hamilton, 2000; Street, 1984) linked to written activities. Thus, the study of written communication has a situated character, from a historical and social perspective (Barton, 1994). In this study, we have presented some relevant findings regarding literacy development and its relation to the home and family contexts, as well as their interaction with formal school learning. Pupils' different literacy practices are inter-related in various domains. Young learners develop their literacy practices according to the different communication needs they have in the school domain (completing a written task, reading a text, etc.) or in the domains of the home, the neighborhood, friends, and so on (making an appointment, answering an e-mail, finding a video on the Internet) (Ivanič \& Moss, 1991). This is because in families a multimodal literacy is promoted to meet daily communication needs. These literacy practices in the domains of the home, friends, and so on are situated in individual reading and writing activities.

However, the school does not incorporate multimodal literacy (Camitta, 1993), and teachers promote a monomodal literacy that allows pupils to respond essentially to school needs. Thus, literacy practices developed in the school domain are located in individual reading and writing activities and the social activities of reading and writing related to the formal learning.

Monomodal and multimodal literacy practices show not only the character of literacy, but also the inter-relationship between different domains of young learners, which confirms the value of an ecological approach to the study of literacy (Syverson, 2008). Knowledge of the multiliteracies of primary school pupils should become the starting point of literacy at school. Learning for life would be enhanced and the need to promote practical learning in a social context would be underscored (Unsworth, 2001). 


\section{Note}

1. The version for students can be found at https://es.surveymonkey.com/r/ZCTNDGQ, the family version can be found at https://es.surveymonkey.com/r/9WSL63J, and the version for teachers at https://es.surveymonkey. com/r/9W9YGTV.

\section{Acknowledgments}

This research project, titled "Ecosystems of the Written Language in Pupils of the Second Cycle of Basic General Education in Costa Rica," was a collaboration of the University of Seville (US) together with the Instituto de Investigación en Educación (INIE), University of Costa Rica (UCR). In this regard, we thank the collaboration of the INIE staff and resources, led by Dr. Jacqueline Garcia Fallas of the University of Costa Rica. Also, we would like to thank Professor Constant Leung (Centre for Language, Discourse \& Communication, King's College London) and Hilary McQueen (UCL Institute of Education) for his helpful support and advice.

\section{Funding}

Funding was provided by Santander University Foundation.

\section{ORCID}

Fernando Guzmán-Simón (D) http://orcid.org/0000-0001-7189-1849

Celia Moreno-Morilla (iD http://orcid.org/0000-0003-0566-4319

Eduardo García-Jiménez (D) http://orcid.org/0000-0002-5885-8267

\section{References}

Ames, P. (2005). Multigrade schooling and literacy: Linking literacy learning in home, community, and primary school in the Peruvian Amazon. In B. Street (Ed.), Literacies across educational contexts. Mediating learning and teaching (pp. 64-83). Philadelphia, PA: Caslon Publishing.

Authors. (2014). The publication information should not be present.

Barton, D. (1991). The social nature of writing. In D. Barton \& R. Ivanič (Eds.), Writing in the community (pp. 1-13). London, England: Sage.

Barton, D. (1994). Literacy. An introduction to the ecology of written language. Oxford, England: Blackwell Publishing. Barton, D., \& Hamilton, M. (1998). Local literacies. Reading and writing in one community. London, England: Routledge. Barton, D., \& Hamilton, M. (2000). Literacy practices. In D. Barton, M. Hamilton, \& R. Ivanič (Eds.), Situated literacies. Reading and writing in context (pp. 7-15). London, England: Routledge.

Barton, D., \& Lee, C. K. M. (2012). Redefining vernacular literacies in the age of Web 2.0. Applied Linguistics, 33(3), 282-298. doi:10.1093/applin/ams009

Baynham, M. (1995). Literacy practices: Investigating literacy in social contexts. London, England: Routledge.

Bearne, E. (2003). Rethinking literacy: Communication, representation and text. Literacy, 37(3), 98-103. doi:10.1046/ j.0034-0472.2003.03703002.x

Bezemer, J., \& Kress, G. (2008). Writing in multimodal texts: A social semiotic account of designs for learning. Written Communication, 25(2), 166-195. doi:10.1177/0741088307313177

Brandt, D., \& Clinton, K. (2002). Limits of the local: Expanding perspectives on literacy as a social practice. Journal of Literacy Research, 34(3), 337-356. doi:10.1207/s15548430jlr3403_4

Camitta, M. (1993). Vernacular writing: Varieties of literacy among Philadelphia high dchool dtudentd. In B. Street (Ed.), Cross-vultural spproaches to literacy (pp. 228-246). Cambridge, England: Cambridge University Press.

Carrington, V. (2005). New textual landscapes, information and early literacy. In J. Marsh (Ed.), Popular culture, new media and digital literacy in early childhood (pp. 13-27). London, England: Routledge.

Cervetti, G., Damico, J., \& Pearson, P. D. (2006). Multiple literacies, new literacies, and teacher education. Theory Into Practice, 45(4), 378-386. doi:10.1207/s15430421tip4504_12

Clerehan, R., Guillermin, F., Epstein, J., \& Buchbinder, R. (2016). Using the evaluative linguistic framework for questionnaires to assess comprehensibility of self-report health questionnaires. Value in Health, 9, 335-342. doi:10.1016/j.jval.2016.01.008

Compton-Lilly, C., \& Halverson, E. (Eds.). (2014). Time and space in literacy research. New York, NY: Routledge.

CONARE. (2013). Desempeño de la educación general básica y el ciclo diversificado. In Estado de la educación costarricense (pp. 135-195). San José, Costa Rica: Editorama. 
Cope, B., \& Kalantzis, M. (2009). Multiliteracies: New literacies, new learning. Pedagogies. An International Journal, 4 (3), 164-195. doi:10.1080/15544800903076044

Cox, S., \& Robinson-Pant, A. (2005). Communicative practices and participation in school councils in primary schools in the United Kingdom. In B. Street (Ed.), Literacies across educational contexts. Mediating learning and teaching (pp. 43-63). Philadelphia, PA: Caslon Publishing.

Creswell, J. W. (2009). Research design. Qualitative, quantitative and mixed methods approaches. Los Angeles, CA: Sage.

Creswell, J. W., \& Plano Clark, V. L. (2011). Designing and conducting. Mixed methods research. Los Angeles, CA: Sage.

Davies, H. C., Halford, S. J., \& Gibbins, N. (2012). Digital natives? Investigating young people's critical skills in evaluating web based information. Proceedings of the 3rd Annual ACM Web Science Conference, 78-81. ACM. Retrieved from http://eprints.soton.ac.uk/340985/1/Questioning\%20Digital\%20Native\%27s\%20Skills\%20\% 28ePrints\%29.pdf.

Douglas, M. (1970). Símbolos naturales: Exploraciones en cosmología. Madrid, Spain: Alianza.

Flewitt, R. (2006). Using video to investigate preschool classroom interaction: Education research assumptions and methodological practices. Visual Communication, 5(1), 25-51. doi:10.1177/1470357206060917

Folkestad, G. (2006). Formal and informal learning situations or practices $v$ s formal and informal ways of learning. British Journal of Music Education, 23(2), 135-145. doi:10.1017/S0265051706006887

Gee, J. P. (1990). Social linguistics and literacies: Ideology in discourses. Bristol, PA: The Falmer Press.

Gee, J. P. (1999). An introduction to discourse analysis. Theory and method. London, England: Routledge.

Gee, J. P. (2004). Situated language and learning. A critique of traditional schooling. Lancaster, England: Lancaster University.

Gil-Flores, J., Torres-Gordillo, J. J., \& Perera Rodríguez, H. (2012). The role of online reader experience in explaining students' performance in digital reading. Computers \& Education, 59(2), 653-660. doi:10.1016/j. compedu.2012.03.014

Halliday, M. A. K. (1978). Language as social semiotic: The social interpretation of language and meaning. Baltimore, MD: University Park Press.

Hamilton, M. (2010). The social context of literacy. In N. Hughes \& I. Schwab (Eds.), Teaching adult literacy: Principles and practice (pp. 7-28). Maidenhead, England: Open University Press.

Harris, J. (1989). The idea of community in the study of writing. College Composition and Communication, 40, 11-22. doi: $10.2307 / 358177$

Healy, A. (2008). Expanding student capacities. In A. Healy (Ed.), Multiliteracies: Pedagogies for diverse learners (pp. 2-29). Sydney, Australia: Oxford University Press.

Heath, S. B. (1983). Ways with words: Language, life, and work in communities and classrooms. Cambridge, MA: Cambridge University Press.

Hull, G., \& Schultz, K. (Eds.). (2002). School's out! Bridging out-of-school literacies with classroom practice. New York, NY and London, England: Teachers College Press.

Hymes, D. H. (1996). Ethnography, linguistics, narrative inequality: Toward and understanding of voice. London, England: Taylor \& Francis.

Ivanič, R., Edwards, R., Barton, D., Martin-Jones, M., Fowler, Z., Hughes, B., ... Smith, J. (2009). Improving learning in college. Rethinking literacies across the curriculum. London, England: Routledge.

Ivanič, R., \& Moss, W. (1991). Bringing community writing practices into education. In D. Barton \& R. Ivanič (Eds.), Writing in the community (pp. 191-223). London, England: Sage.

Ivankova, N. V., Creswell, J. W., \& Stick, S. L. (2006). Using mixed-methods sequentia explanatory design: From theory to practice. Field Methods, 18(1), 3-20. doi:10.1177/1525822X05282260

Jewitt, C. (2008). Multimodality and literacy in school classrooms. Review of Research in Education, 32(1), $241-267$. doi:10.3102/0091732X07310586

Jolliffe, I. T. (2013). Principal component analysis. New York, NY: Springer.

Kalantzis, M., \& Cope, B. (2000). Changing the role of schools. In B. Cope \& M. Kalantzis (Eds.), Multiliteracies. Literacy learning and the design of social futures (pp. 116-144). London, England: Routledge.

Knobel, M., \& Lankshear, C. (Eds.). (2007). A new literacies sampler. New York, NY: Peter Lang.

Kress, G. (2003). Literacy in the new media age. London, England: Routledge.

Kress, G. (2010). Multimodality. A social semiotic approach to contemporary communication. London, England: Routledge.

Lancaster, L. (2003). Beginning at the beginning: How a young child constructs time multimodality. In C. Jewitt \& G. Kress (Eds.), Multimodal literacy (pp. 107-122). New York, NY: Peter Lang.

Lankshear, C., \& Knobel, M. (2003). New literacies changing knowledge and classroom learning. Buckingham, England: Open University Press.

Larson, J. (2005). Breaching the classroom walls: Literacy learning across time and space in an Elementary School in the United States. In B. Street (Ed.), Literacies across educational contexts. Mediating learning and teaching (pp. 84104). Philadelphia, PA: Caslon Publishing.

Larson, J. (2006). Multiple literacies, curriculum, and instruction in early childhood and elementary school. Theory Into Practice, 45(4), 319-329. doi:10.1207/s15430421tip4504_5

Lavrakas, P. J. (2008). Self-administrated questionnaires. In P. J. Lavrakas (Ed.), Enclycopedia of survey research methods (pp. 803-804). Los Angeles, CA: Sage. doi:10.4135/9781412963947.n521 
Lillis, T. (2013). The sociolinguistics of writing. Edinburgh, Scotland: Edinburgh University Press.

Luke, C. (2000). Cyber-schooling and technological change. In B. Cope \& M. Kalantzis (Eds.), Multiliteracies. Literacy learning and the design of social futures (pp. 67-88). London, England: Routledge.

Lytra, V. (2007). Play frames and social identities. Contact encounters in a Greek primary school. Amsterdam. The Netherlands/ Philadelphia, PA: John Benjamins Publishing Company.

Martos García, A. E. (2010). Las prácticas de lectura/escritura y los enfoques etnográfico y geográfico. Didáctica: Lengua Y Literatura, 22, 199-229.

Maybin, J. (Ed.). (1994). Language and literacy in social practice: A reader. Clevedon, England: The Open University.

Maybin, J. (2006). Children's voices. Talk, knowledge and identity. Basingstoke, England: Palgrave Macmillan.

Merchant, G., Gillen, J., Marsh, J., \& Davies, J. (Eds.). (2013). Virtual literacies. Interactive spaces for children and young people. London, England: Routledge.

Ministerio de Educación Pública. (2012). Informe nacional de factores asociados al rendimiento académico en las pruebas nacionales diagnósticas, tercer ciclo de la educación general básica, 2010. San José, Costa Rica: Author.

Ministerio de Educación Pública. (2013). Eficiencia del sistema educativo costarricense. San José, Costa Rica: Author.

Molina Fallas, K., \& Cruz Romero, R. (2013). La cultura en la era digital. In Hacia la sociedad de la información y el conocimiento: Informe Anual Hacia la Sociedad de la Información y el Conocimiento (pp. 401-439). Universidad de Costa Rica: SIEDIN.

Montero, E., Rojas, S., \& Zamora, E. (2014). Costa Rica en las pruebas PISA 2012. In Quinto informe del estado de la educación. Retrieved from http://www.estadonacion.or.cr/index-ee/index-ee-tema\#primaria-y-secundaria

Neuman, S. B., \& Celano, D. (2001). Access to print in low-income and middle-income communities: An ecological study of four neighbourhoods. Reading Research Quarterly, 36(1), 8-26. doi:10.1598/RRQ.36.1.1

OECD. (2014). PISA 2012 results: What students know and can do. Student performance in mathematics, reading and science. (Vol. I, Rev. edition). Paris, France: Author. doi:10.1787/9789264201118-en

OECD. (2016). PISA 2015 results (Vol. I): Excellence and equity in education. Paris, France: Author. doi:10.1787/ 9789264266490-en

Pahl, K. (2003). Children's text-making at home: Transforming meaning across modes. In C. Jewitt \& G. Kress (Eds.), Multimodal literacy (pp. 138-154). New York, NY: Peter Lang.

Pahl, K., \& Rowsell, J. (2012). Literacy and education. Understanding the new literacy studies in the classroom. London, England: Sage.

Palys, T. (2008). Purposive sampling. In L. M. Given (Ed.), The Sage encyclopaedia of qualitative research methods (pp. 697-698). Los Angeles, CA: Sage.

Rogers, R., \& Elias, M. (2012). Storied selves: A critical discourse analysis of young children's literate identifications. Journal of Early Childhood Literacy, 12(3), 259-292. doi:10.1177/1468798411417370

Street, B. V. (1984). Literacy in theory and practice. Cambridge, England: Cambridge University Press.

Street, B. V. (1988). Literacy practices and literacy myths. In R. Säljö (Ed.), The written word: Studies in literate thought and action (pp. 59-72). Berlin/Heidelberg,Germany: Springer.

Street, B. V. (1994). The new literacy studies: Implications for education and pedagogy. Changing English, 1(1), 113126. doi:10.1080/1358684940010109

Street, B. V. (1995). Social literacies: Critical approaches to literacy in development, ethnography and education. London, England: Longman.

Street, B. V. (1997). The implication of the "new literacy studies" for literacy education. English in Education, 31(3), 45-59. doi:10.1111/j.1754-8845.1997.tb00133.x

Street, B. V. (2000). Literacy events and literacy practices. In K. Jones \& M. Martin-Jones (Eds.), Multilingual literacies: Reading and writing different worlds (pp. 17-29). Amsterdam, The Netherlands: John Benjamins.

Street, J. C., \& Street, B. V. (1991). The schooling of literacy. In D. Barton \& R. Ivanič (Eds.), Writing in the community (pp. 143-166). London, England: Sage.

Syverson, P. (2008). An ecological view of literacy learning. Literacy, 42(2), 109-117. doi:10.1111/read.2008.42.issue-2

Tashakkori, A., \& Teddlie, C. (1998). Mixed methodology: Combining qualitative and quantitative approaches. Thousand Oaks, CA: Sage.

Tierney, R. J., Bond, E., \& Bresler, J. (2006). Examining literate lives as students engage with multiple literacies. Theory Into Practice, 45(4), 359-367. doi:10.1207/s15430421tip4504_10

Unsworth, L. (2001). Teaching multiliteracies across de curriculum. Changing contexts of text and image in classroom practice. Buckingham, England: Open University Press.

Upton, G., \& Cook, I. (2014). A dictionary of statistics. Oxford, England: Oxford University Press.

Walsh, M. (2010). Multimodal literacy: What does it mean for classroom practice? Australian Journal of Language and Literacy, 33(3), 211-239.

Warchauer, M. (2007). The paradoxical future of digital learning. Learning Inquiry, 1(1), 41-49. doi:10.1007/s11519007-0001-5 